\title{
THE NECTAR SECRETION OF MAPLE (ACER PLATANOIDES L.) AND SYCAMORE (A. PSEUDOPLATANUS L.)
}

\author{
Oldrich HARAGSIM \\ Institut of Apiculture, Dol, 25266 Libčice n. Vlt. Czechoslovakia
}

\section{SUMMARY}

Our measurements corroborate and prove the viewpoints of older authors and heekeepers who assert that maple and sycamore can be held as good nectar and pollen sources. The flow from maple has a stimulative importance. Flow from sycamore, though also being of stimulative importance, may give an appreciable yield of sugar matter which is kept in the form of honey reserves. However, this honey is as a rule mixed with fruit-tree or willowtree honey. Specific maple and sycamore honey is rare and has not yet been encountered in our practice. Both species of Aceraceae can be recommanded for green spots and zones in residential areas where they have an important aesthetic and landscape-decorating function while, at the same time, enriching the honey flow and ensuring good beecolony development.

Aceraceae are forest and park tree species, largely occuring in the moderate zone of the northern hemisphere. About 150 species of this family are known, maple (Acer platanoides L.) and sycamore (A. pseudoplatanus L.) being the most wide-spread species in central Europe. Maple and sycamore blossom early in spring, giving aboundant pollen and nectar to the bees. Further, a majority of the species of Aceraceae are hosts of aphids of the Chaitophoridae and Callaphididae families which belong to honeydew producers; thus, Aceraceae serve also as ample source of honeydew.

Beekeepers consider Aceraceae as outstanding nectar producers (JANIŠ 1789, LišKa 1877, Kitzberger 1924, Hansson 1968, Maurizio and Grafl 1969 and others). However, only some authors did measure the actual nectar secretion of individual species : BoËTius 1946 in maple, JAroszY NSKA 1960 in Tatarian maple (A. tataricum L.). Similarly, nothing is known about single species acer honey since such honey does not occur almost at all and the early 
spring flow provides good stimulation feeding during the spring development of the colonies (RUTTNER 1957).

The object of our effort was to study the biology of flowers and inflorescences of $A$. platanoides and $A$. pseudoplatanus. A detailed monographical study will be published in the periodical Silvae genetica (Haragsim, SvoboDova, Slavizova - in press). The results of the measurements of nectar secretion of flowers are treated in this brief paper.

Nectar secretion was measured by the standard method by means of glass micro-pipettes on the flowers of trees growing in the mixed stands around the Apicultural Research Institute at Dol. The age of the trees is about 6080 years, height $25-30 \mathrm{~m}$; the soil is alluvial and crumby, with good supply of water and, as seen from indicator plants, with a good supply of nutrients.

Twenty-four hours before nectar collection the flowers were isolated in organdie sacs. The flowers were collected for measurement between 8 and 9 o'clock A.M., always from several inflorescences at $2-4 \mathrm{~m}$ height both on the northern and southern side of the tree. The sugar percentage of the nectar was measured by means of a refractometer. The sugar value was calculated by multiplying the average amount of nectar with the average sugar content. The t-test was used for the evaluation of the significance of the data obtained.

The flower nectary of Acer platanoides has a disk shape and is borne on the receptacle between the floral envelopes and the gynaeceum. In the functionally pistillate flowers it has a circular shape. The disk is lobular along the circumference, having 2-3 deep recesses, directed from the centre to the edge. It has a yellow-green colour and is covered with a sugary layer of nectar in the mean flowering time. Nectar flows towards the edge and is stored under the lobular fold. The epidermis of the disk consists of hexagonal cells, either isodiametric or elongated in one direction, and slightly convex near the surface. The average lenght of epidermal cells is $27.5 \mu \mathrm{m}$. A thin cuticle is on their surface. Epidermal cells are interlanced with pores through which the nectar gets to the surface of the disk (Fig. 1). The pores consist of two contracting cells between which a pore hole is kept open. The contracting cells are $24 \mu \mathrm{m}$ long, in average, and are oriented in all directions. The pores are surounded by 4-7 epidermal cells. The average number of pores between stamens was 11.1. The epidermis is supported by secretory tissue of several layers, consisting of tiny cells closely adjacent to each other, having a size about $16,0 \mathrm{~km}$ (unlike the cells of parenchyma which are about twice as large, $29.11 \mu \mathrm{m}$ in diameter). The vascular bundles which are responsible for supplies to the nectary are branched in the receptacle into a great number of small bundles, reaching up to the secretory part of the tissue; however, the tissue of the nectary itself has no vascular bundles. 

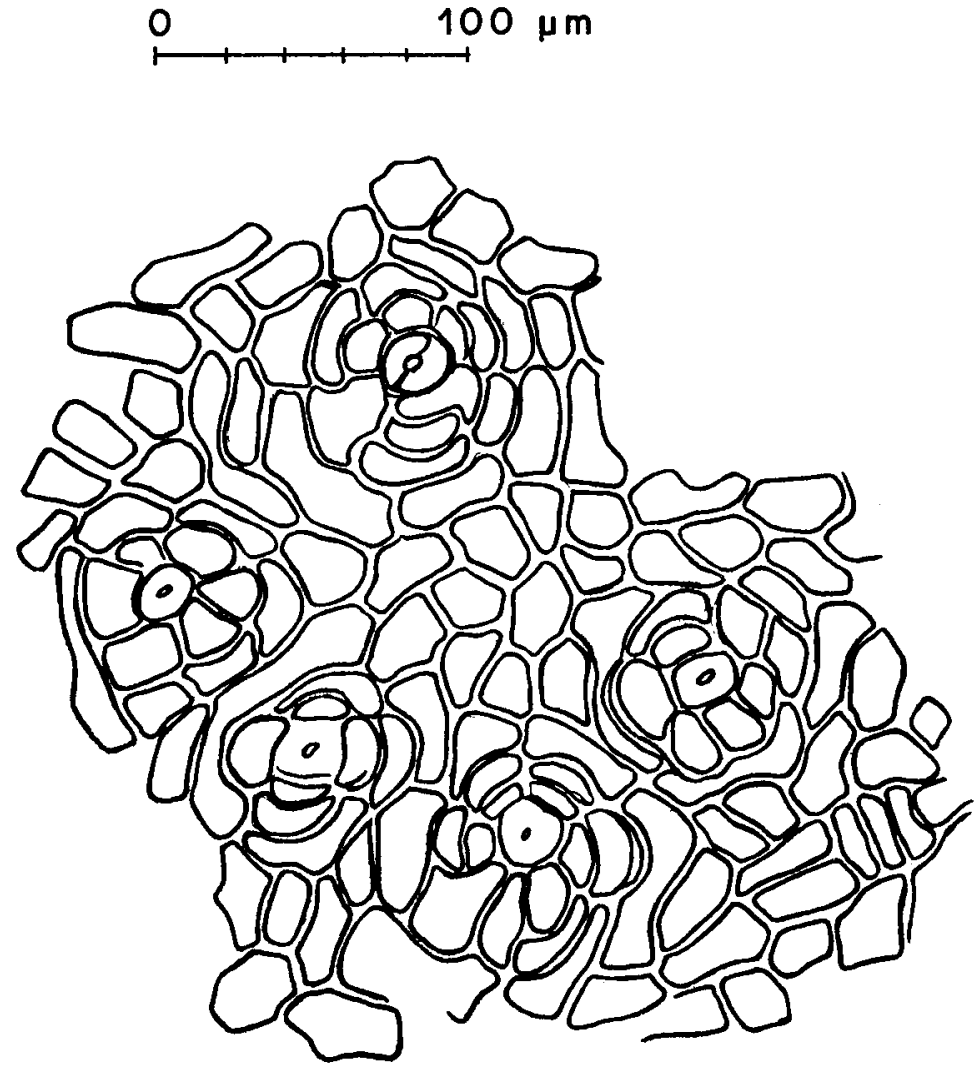

Fig. 1. - A part of nectary surface of Acer platanoides $L$.

As to the anatomic and morphological structure, the nectary of Acer platanoides is the same as that of A. pseudoplatanus (Fig. 2). However, the epidermal cells of the latter are smaller-about $19,82 \mu \mathrm{m}$ on average, where as the guard cells of the pores are, on the other hand, larger $-26.5 \mu \mathrm{m}$. The nectary of A. pseudoplatanus has a much smaller number of pores per unit of disk area, the average number of pores between stamens being 3.0. The vascular bundles reach up to the secretory part of the nectary, the secretory tissue having no vascular bundles.

The nectar production of $A$. platanoides was measured in two years in 2.137 flowers. However, in majority of the measurements no distiction was made between the staminate and pistillate flowers (Tabel 1). For the whole flowering season the staminate flowers $(n=18)$ secreted $4.13 \mathrm{mg}$ nectar, the sugar value being $1.42 \mathrm{mg}$, and pistillate flowers $(\mathrm{n}=14)$ secreted $6.32 \mathrm{mg}$ nectar at sugar value of $1.60 \mathrm{mg}$. 


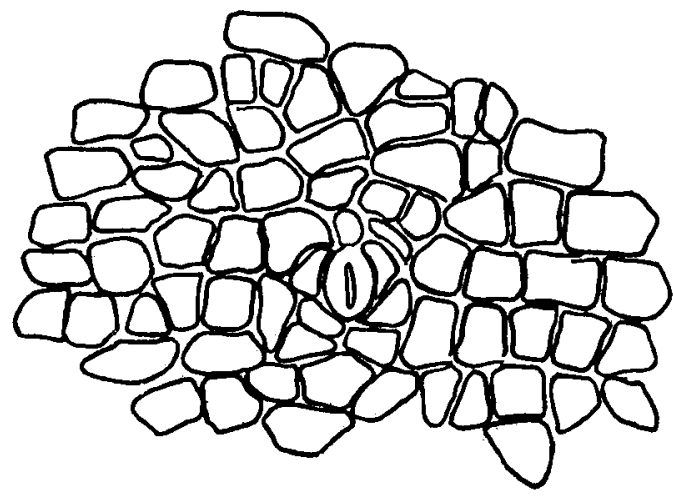

$50 \mu \mathrm{m}$

Fig. 2. - A part of nectary surface of Acer pseudoplatanus $L$.

TABL. 1. - Nectar production of maple and sycamore.

\begin{tabular}{|c|c|c|c|c|}
\hline $\begin{array}{c}\text { Year of } \\
\text { measurement }\end{array}$ & $\begin{array}{l}\text { No of } \\
\text { flower }\end{array}$ & Nectar in $\mathbf{m g}$ & $\begin{array}{c}\text { Sugar content } \\
\%\end{array}$ & $\begin{array}{l}\text { Sugar value } \\
\text { in } \mathrm{mg}\end{array}$ \\
\hline \multicolumn{5}{|c|}{ Acer platanoides $L$. } \\
\hline 1971 & 1.023 웋 & $0,56 \pm 0,28$ & $34,48 \pm 4,26$ & $0,19 \pm 0,01$ \\
\hline 1972 & 1.114 유 & $0,42 \pm 0,36$ & $30,02 \pm 3,81$ & $0,12 \pm 0,02$ \\
\hline \multicolumn{5}{|c|}{ Acer pseudoplatanus } \\
\hline 1971 & 860 웅 & $0,96 \pm 0,62$ & $44,05 \pm 4,3$ & $0,43 \pm 0,04$ \\
\hline 1971 & 1.120 क & $0,91 \pm 0,82$ & $40,11 \pm 3,8$ & $0,36 \pm 0,02$ \\
\hline 1972 & 1.461 우 & $0,90 \pm 0,03$ & $37,75 \pm 10,9$ & $0,31 \pm 0,07$ \\
\hline 1972 & 1.340 o & $1,16 \pm 0,47$ & $46,6 \pm 7.3$ & $0,54 \pm 0,04$ \\
\hline
\end{tabular}

In $A$. pseudoplatanus nectar is stored between the trichomes of the glandular target of the flower or on its periphery between the petals and sepals. It is waterly clear or slightly yelowish. In the first year of measurement, the following average values were measured-Table $I$.

In nectar production statistically significant differences were ascertained between the pistillate and staminate flowers of sycamore, and the pistillate flowers produce more nectar with a greater sugar content. For whole flowering season a pistillate flower $(\mathrm{n}=19)$ produced $5.92 \pm 1.29 \mathrm{mg}$ nectar, the average sugar content being $43.2 \%$, and staminate flower $(\mathrm{n}=24) 4.87$ $\pm 1.32 \mathrm{mg}$ nectar, the average sugar content being $39.0 \%$. The sugar value being $1.90 \mathrm{mg}$, respectivly $2.56 \mathrm{mg}$. 


\section{ZUSAMMENFASSUNG}

\section{DIE NEKTARSEKRETION VOM SPITZAHORN (Acer platanoides L.) UND BERGAHORN (A. pseudoplatanus L.)}

Unsere Messungen bestätigen die Erfahrungen früherer Autoren und von Imkern, daß Spitzahorn und Bergahorn als ergiebige Nektar- und Pollenqueilen zu betrachten sind. Der Spitzahorn-Nektar hat eine Bedeutung für die Frühjahrsentwicklung der Bienen, während die Bergahorn-Tracht daneben auch eine gute Quelle für die Bildung von Honigreserven ist. Dabei entsteht meist ein Mischhonig aus Ahorn-, Obstbaum- und Weidentracht. Spezifische Spitzoder Bergahorn- Honige sind sicher selten und uns noch nicht begegnet. Beide Ahornarten sind empfehlenswerte Pflanzen für die Begränung auch von Wohngebieten, wo sie nicht nur ästhetisch und landschaftsgärtnerisch bedeutsam sind, sondern auch als Trachtpflanzen für die Bienen dienen können.

\section{RÉSUMÉ \\ LA SÉcrétion NECTARIFÈre de L'Érable (Acer platanoides L.) ET DU SYCOMORE (A. pseudoplatanus L.)}

Nos mesures confirment les points de vue des anciens auteurs et des apiculteurs, selon lesquels ont peut tenir l'érable et le sycomore pour de bonnes sources de nectar et de pollen La miellée de l'érable joue un rôle stimulateur dans le développement de la colonie au printemps. Celle du sycomore, bien qu'ayant également un rôle stimulateur, peut donner lieu à une récolte appréciable stockée sous la forme de réserves de miel. Mais ce miel est généralement mélangé à du miel d'arbres fruitiers ou du miel de saule. Le miel monofloral d'érable et de sycomore est rare et nous ne l'avons pas rencontré en pratique. Ces deux espèces d'Aceraceae peuvent être recommandées pour les espaces verts des zones résidentielles, où elles remplissent une fonction esthétique et décorative, tout en accroissant la flore mellifère.

\section{REFERENCES}

Boetrus J., 1948. - Ueber den Verlauf der Naktarabsonderung einiger Blütenpflanzen. Beih. Schweiz. Bienenztg, 2 (17); 257-317.

Buchenau F., 1861. - Morphologische Bemerkungen über einige Acerineen. Bot. Ztg. 19 (37), 283-286.

Havsson A., 1968. - Biväxter. - Örebro, p. 111.

Haragsim O., 1970. - Die Bedeutung des Bergahorns für die Bienenzucht. Die Bienenpflege, $7,142-143$.

Haragsim O., Svobodová D., Slaviková Z., 1978. - Floral biology of maple and sycamore and their nectar secretion. - Silvae genetica - in press.

J ANıš J. A., 1789. - Aučenlivé spravování včel pro vseobecného krajana v Království Českém. Praha, p. 112.

Jaroszynska T., 1960. - Biologia kwitnenia i nektarowanija klonu tatarskiego (Acer tataricum). - Pszezeln. Zesz. Nauk., 4, (3-4), 153-165.

KrTzBerger I.F., 1924. - Rostliny medonosné. - Praha, p. 264. 
Kugler H., 1970. - Blütenökologie. - Stuttgart, 2e édit., p. 346.

LIšKa J., 1877. - Chov včel. - Praha, p. 284.

Maurizio A., Grafl I., 1969. - Das Trachtpflanzenbuch. München, p. 288.

Ruttner F., 1957. - Frühtracht vom Bergahorn. - 1957 Bienenvater, 78, 132-135.

Svorodová D., 1972. - Květní ekologie javoru mlécného (A. platanoides) a jeho kulturních odrüd. - Acta musei silesiae - Dendrologia 11/2, 163-170.

VASILJEv A. E., 1969. - Submicroscopical morphology of nectary cells. Bot. zurnal, 54, 7, 1015-1031. (in Russian). 